\title{
Measuring Services Trade Liberalization and Its Impact on Economic Growth: An Illustration
}

\author{
Aaditya Mattoo \\ The World Bank \\ Randeep Rathindran \\ HDR Inc. \\ Arvind Subramanian \\ International Monetary Fund
}

\begin{abstract}
The paper has three purposes. First, it explains how the impact of liberalization of service sectors on output growth differs from that of liberalization of trade in goods. Second, it suggests a policy-based rather than outcome-based measure of the openness of a country's services regime. Such openness measures are constructed for two key service sectors, basic telecommunications and financial services. Finally, it provides some econometric evidence-relatively strong for the financial sector and less strong, but nevertheless statistically significant, for the telecommunications sector-that openness in services influences long run growth performance. Our estimates suggest that countries with fully open telecom and financial services sectors grow up to 1.5 percentage points faster than other countries.
\end{abstract}

\footnotetext{
*Corresponding address: Aaditya Mattoo, Development Research Group, World Bank, Room MC3-335, 1818 H St, NW, Washington, DC 20433, USA. Tel: +1-202-458-7611, Fax: +1-202-522-1159, E-mail: amattoo@worldbank.org. Authors can be reached at amattoo@worldbank.org, randeep.rathindran@ hdrinc.com and asubramanian@imf.org.respectively

(C2006-Center for International Economics, Sejong Institution, All Rights Reserved.
} 
- JEL classifications: F13, F43, G2, G28

- Key words: Liberalization, Economic Growth, Services, Regulation

\section{Introduction}

A spate of empirical cross-country studies by Dollar (1992), Sachs and Warner (1995), Ben-David (1993), Edwards (1998) and Coe et al. (1997) suggests that the impact of liberalization of trade in goods on the long run rate of economic growth is positive, although a subsequent paper (Rodriguez and Rodrik (1999)) questions the robustness of the results. While the state of the debate seems to be in ferment, it is surprising that comparable analysis depicting the impact of services trade liberalization on economic growth is more sparse. ${ }^{1}$

If liberalizing trade in goods, which typically accounts for less than half of GDP in most countries, and even less than a third of output in the industrial economies, can affect economy-wide growth, then there should be comparable gains from liberalizing services that are becoming increasingly tradable and that account for a large and growing share of output in most countries.

The paper has three purposes. First, it explains how the impact of liberalization of service sectors (hereafter "services trade liberalization") on output growth differs from that of liberalization of trade in goods (hereafter "goods liberalization".) Second, it suggests a measure of the openness of a country's services regime. Such openness measures are constructed for two key service sectors, basic telecommunications and financial services. Finally, these openness measures are introduced in cross-country growth regressions à la Barro (1997) and Sachs-Warner $(1995,1997)$ to test whether the openness of the policy regime in services has an impact on long run economic growth.

The paper is organized as follows. Section II of this paper contrasts liberalization in goods with that in services and explains why the latter can be expected to lead to both static and dynamic improvements in economic performance. Section III of the paper reviews some of the existing literature on the links between services trade and long run economic growth. Section IV presents our methodology regarding construction of the openness indices for the telecommunications and financial services sectors. A description of the data and the regression results can be found in

${ }^{1}$ Verikos and Zhang (2001) at the Australian Productivity Commission have estimated global gains from liberalizing trade in telecommunications and financial services. However, their estimates pertain to the static gains in the level of real GNP, rather than its growth rate. 
section V of the paper. Section VI spells out our conclusions.

\section{The Static and Dynamic Benefits of Liberalising Trade in Services}

It is not difficult to identify the many ways that efficient services contribute to improved economic performance. An efficient and well-regulated financial sector leads to an efficient transformation of savings to investment, ensuring that resources are deployed where they have the highest returns; benefits also arise from increased financial product variety and better risk-sharing in the economy. In the case of telecommunications, improved efficiency generates economy-wide benefits as telecommunications are a vital intermediate input and are also crucial to the dissemination and diffusion of knowledge-the spread of the internet and the dynamism that that has lent to economies around the world is telling testimony to the importance of telecommunications services. Similarly, transport services contribute to the efficient distribution of goods within a country and a country's ability to participate in global trade, thus helping realize the benefits of integration. Although these are the more prominent services, others are also crucial-business services such as accounting and legal services are important in reducing transaction costs. Collier and Gunning (1999) consider high transaction costs as the most significant impediment to economic growth in Africa. According to Summers (1999), the single most important innovation in the history of the American capital markets was the idea of generally accepted accounting principles. Software development is the foundation of the modern information-based economy. Education and health services are necessary in building up the stock of human capital, a key ingredient in long run growth performance.

Ideally, we would seek to measure the impact of liberalization in each of these sectors, but the paucity of data forces a narrower focus. Our formal analysis deals with the core infrastructure services, finance and telecommunications, the only services sectors for which it was possible at this stage to put together comprehensive cross-country data sets.

\section{A. Static benefits: Goods and Services}

In static models without market imperfections (such as monopolistic market structures, internal and external economies of scale or other distortions), restrictions on trade in goods reduce the level of real GDP, which is equivalent to a loss 
in welfare. The restriction creates a wedge between domestic and foreign prices, leading to a loss in consumer surplus that is greater than the gain in producer surplus arising from higher domestic production and in government revenue. ${ }^{2}$ The net impact on welfare is therefore negative. Restrictions on trade in services can, in principle, be expected to have similar welfare costs as they too drive a wedge between domestic and foreign prices of services. Many of the empirical sectoral studies produced so far support this contention. ${ }^{3}$ It has been suggested that in the case of services, there is an additional twist in that many services are inputs into production and inefficient production of such services acts as a tax on production. Thus, goods liberalization in the absence of services liberalization could well result in lowering the effective protection for goods, highlighting the need for the latter to keep pace with the former. ${ }^{4}$ Analytically, however, the case for liberalizing services inputs is no different from that relating to goods inputs.

For instance, Deardoff (2001) has argued that there are particularly large gains from eliminating barriers to trade in services like transport that facilitate trade. In addition to the standard triangles of dead-weight loss gained in the services sector itself, there are the rectangles of efficiency gains from lower trading costs in the user sector (see Annex 1). However, there still is no reason why liberalization should affect the long-run growth rate.

\section{B. Dynamic Benefits}

In examining the link between services and growth, a key question is why the link between liberalization of services and economic growth might be expected to be different from that between goods liberalization and growth.

\section{Liberalizing Trade in Goods and Growth}

In theoretical models, the impact of trade liberalization on economic growth is either absent or ambiguous. In a conventional neoclassical growth model, trade does not affect the equilibrium or steady state rate of output growth because, by assumption, growth is determined by exogenously given technological progress. In two-sector models of this kind, trade policy affects the allocation of resources

\footnotetext{
${ }^{2}$ The presence of imperfections opens up a plethora of possibilities in which the effects of trade policies are typically indeterminate, depending on the prior distortion.

${ }^{3}$ See Hoekman and Braga (1997) for a review.

${ }^{4}$ See Hoekman and Djankov (1997) for evidence on Egypt.
} 
between sectors and hence the steady-state level of savings and capital accumulation. This can have a one-off effect on the steady-state level of output (which can be positive or negative depending on how savings and capital accumulation are affected by trade policy), but not on the rate of growth.

However, in endogenous growth models, the impact of trade liberalization on output growth can be positive or negative, as emphasized by Rodriguez and Rodrik (1999). If the resource allocation effects of trade policy changes promote sectors or activities that generate more long-run growth, the impact is positive, and negative otherwise. For example, if trade liberalization shifts resources into manufacturing and away from agriculture, this will have a positive impact on long run growth if manufacturing generates greater positive externalities or creates knowledge, that is, if it possesses the attributes necessary for endogenous growth. The impact of trade policy on growth is thus an empirical question. ${ }^{5}$

\section{Services trade liberalization and growth}

It does not seem unreasonable to assume that certain services industries, like certain goods industries, possess growth generating characteristics. In sectors like telecommunications, software, financial services and transport, there is considerable scope for learning by doing, knowledge generation, expanding product variety, and upgrading product quality, though the precise extent of these possibilities is an empirical question.

What is it that really distinguishes trade in services from trade in goods? For a number of services, there is no difference: trade is conducted in much the same manner as trade in goods, with the service (say software) produced in one country and supplied cross-border to a consumer in another country. But for many other services, from local phone calls to transportation, the simultaneity of production and consumption implies a need for proximity between the consumer and producer and hence it is necessary for the factors of production (capital and labor) to move to the location of the consumer. ${ }^{6}$ Secondly, barriers to entry in a number of services

\footnotetext{
${ }^{5}$ It is worth noting that increased trade per se can also have a generalized positive impact on growth. For example, trade enables a country to employ a larger variety of intermediate goods and capital equipment which could enhance the productivity of its other resources. Furthermore, trade makes it possible for a country to acquire technology developed worldwide, especially in the form of embodied capital goods. See for example Grossman and Helpman (1991) and the references therein.

${ }^{6}$ While factor movements, especially FDI, also take place to produce goods, the difference is that these are alternatives to cross-border trade, and not essential to supply a particular market.
} 
sectors, ranging from telecommunications to professional services, are maintained not only against foreign suppliers but also against new domestic suppliers. Full liberalization can, therefore, lead to enhanced competition from both domestic and foreign suppliers.

The key difference between trade in goods and services in terms of their growth impact stems from these two distinguishing features of services liberalization: the fact that "imports" of services must be locally produced and that liberalization leads to enhanced competition, both domestic and foreign. ${ }^{7}$ Greater foreign factor participation and increased competition together imply a large scale of activity, and hence greater scope for generating the special growth-enhancing effects. In fact, if foreign participation merely substitutes for domestic factors and the sector does not expand, i.e. the degree of competition remains unchanged, then there cannot be a positive growth impact on account of the scale effect. Conversely, a larger scale achieved merely by eliminating domestic barriers to entry and attracting domestic resources from other sectors would suffice to generate larger endogenous growth. ${ }^{8}$

Secondly, even without scale effects and even if services sectors do not possess endogenous growth attributes, the import of foreign factors that characterizes services sector liberalization could still have positive effects because they are likely to bring with them the source of endogenous growth, namely, technology. If greater technology transfer accompanies services liberalization--either embodied in foreign direct investment or disembodied-the growth effect will be stronger. Coe, Helpman, and Hoffmaister (1999) present empirical evidence demonstrating the impact of technology diffusion-in their case through trade in goods-on total factor productivity growth. At least theoretically, the same should hold true for technology that is diffused through factor flows.

\footnotetext{
${ }^{7}$ Factor mobility per se does not affect growth. For example, even if FDI results in greater capital formation in an economy, the steady state level of growth need not be raised. This can also be seen from a savings-investment perspective. FDI augments the available pool of savings to an economy. In the Solow-Swan growth models, it is a well-known result that higher savings do not permanently raise the growth rate of an economy.

${ }^{8}$ As pointed out by Rodriguez and Rodrik (1999), there are two contradictory impulses on growth emanat-ing from the scale effect described above. Protecting a sector increases its size, leading to higher growth, but it also creates a wedge between domestic and foreign prices imposing a production inefficiency which rises over time exerting a negative impact on growth. The larger the size of the protected sector the larger this impact. Liberalizing a goods producing sector in which a country has a comparative disadvantage, would lead to static and allocative efficiency, but a decline in the size of the sector, i.e., a negative scale effect. By contrast, liberalization of the services sector in which a country has a comparative disadvantage, will also lead to increased scale of activity in addition to the static efficiency gains. This will strengthen the growth impact of liberalization.
} 
We have so far not addressed an important question: In an economy that witnesses large factor flows, what should be the appropriate aggregate measure of welfare? It would seem more appropriate to use GNP as the measure of welfare. If an economy is a consistent net importer (exporter) of factors, using GDP, as the unit of measurement would overstate (understate) the measure of economic welfare. The growth effects that we have so far spoken of refer to all local production, i.e. implicitly to GDP growth.

What can we say about the impact on GNP growth? The impact on GNP growth can be disaggregated into a factor impact and a productivity impact. The impact of liberalization on employment of the nationally-owned factors in the services sector is ambiguous. If the sector was domestically competitive prior to liberalization, then national employment in the sector will certainly decline if the country is a net importer of that service. But if there were also restrictions on domestic entry prior to liberalization, then it is possible that national employment will also expand.

While the employment effect is ambiguous, the productivity of national factors will unambiguously increase due to liberalization of a service sector that requires local presence. Liberalization will lead, first, to an increase in the aggregate scale of the sector and, secondly, to technology spillovers from the local presence of foreign factors. Both effects will enhance the productivity of the nationally owned factors. Taking the employment and productivity effects together we can conclude that the effect of liberalization on GNP is ambiguous.

\section{Review of Existing Literature on the Services - Growth Link}

The existing literature on the link between services and growth focuses primarily on the financial sector. The seminal work is Goldsmith (1969), which stressed the role of financial services in channeling investment funds to their most productive uses, thereby promoting growth of output and incomes. Goldsmith uses the ratio of the value of financial intermediary assets to GNP to gauge financial performance and enters it in a regression with economic growth as the dependent variable. $\mathrm{He}$ finds a "rough parallelism" between economic growth and financial development. However, his approach suffers from endogeneity problems and from not including other growth controls in his regressions.

More recently, King and Levine (1993a) postulate that financial services can affect growth through enhanced capital accumulation and/or technical innovation. They systematically control for other factors affecting long run growth and 
The Differential Impact of Eliminating Barriers to Foreign Provision in Goods and Services

\begin{tabular}{cc}
\hline Liberalizing Services & Liberalizing Goods \\
\hline Foreign Provision: Manner and implications
\end{tabular}

For many services, cross-border trade is not feasible, and so foreign provision requires factor mobility.

Liberalization implies increased scale of domestic activity in import competing sectors because:

foreign factors locate domestically and/or domestic competition increases supported (in sectors like telecom) by more effective regulation.

\section{Static Effects}

Impact is similar for goods and services: liberalization leads to reduced prices and hence improved welfare.

(The fact that services are inputs into production does not make the impact any different from liberalization of goods inputs such as raw materials and capital goods.)

\section{Effect 1}

Spillovers of technology or skills embodied in Liberalizing trade would not have these factor flows will increase productivity of national effects but liberalizing FDI would. ${ }^{9}$ factors of production and hence increase GNP.

\section{Effect 2}

Although scale of domestic activity (involving the In the import-competing sector, activity sum of foreign and domestic factors) is likely to contracts. But general equilibrium effects expand, employment of national factors of production need not. will lead to the expansion of other sectors. If the latter possesses attributes of endogenous The impact on GNP growth will then comprise a growth, liberalization in goods could also factor effect (which could be negative) and a lead to growth.

productivity-enhancing effect which will be positive.

construct additional measures of financial sector development such as the ratio of liabilities of the financial system to GDP and the ratio of gross claims on the private sector to GDP, which they use in growth regressions. They find their measures to be significant and the sizes of their coefficients to imply an economically important relationship. Finally, to counter the endogeneity problem,

\footnotetext{
${ }^{9}$ Technology spillovers could also occur from goods trade liberalization. See Grossman \& Helpman
} (1991). 
they study whether the level of financial sector development in 1960 as measured by one of their ratios, predicts the rate of economic growth over the 1960-1990 period. They find indeed that the level of financial sector development in 1960 is a significant predictor of economic growth over the later period.

Levine (1997) adopts a functional approach to the link between financial development and growth. He identifies five major functions that financial systems perform which help in minimizing transactions costs and improving the allocation of real resources. These functions include facilitating the trading of risk, allocating capital to productive uses, monitoring managers, mobilizing savings through the use of innovative financial instruments and lastly, easing the exchange of goods and services. However, the author admits that research in this area does not sufficiently account for the role of international trade in financial services. Moreover, the paper is silent on the role of policy.

Francois and Schuknecht (1999) regress the growth of per capita real GDP on a measure of the general degree of openness in trade, on certain macroeconomic variables and the concentration ratio for the financial sector. They find a strong positive relationship between growth and financial sector competition. However, the concentration ratio is an outcome based variable, and, moreover, a misleading indicator of the level of competition in the banking system because a concentrated market for banking services can still be contestable. A large number of developed countries such as Canada and many European countries have banking systems characterized by a small number of banks, but still produce competitive outcomes. ${ }^{10}$

\section{Methodology and Data}

In order to undertake the cross-country regression analysis, we take two distinct approaches. Firstly, we construct indices of openness for the telecommunications and financial services sectors. Given the distinctiveness of service sectors discussed above, it is important that the indices capture the two key elements that contribute to the dynamic benefits from services liberalization - degree of competition and extent of foreign ownership. In the empirical work, and in recognition of the fact

\footnotetext{
${ }^{10}$ See Claessens and Klingebiel (1999) and Vives (1998). For example, the Netherlands, Denmark and Finland have concentration ratios (as measured by the share of the 3 largest banks in total banking sector assets) of well over .7 for the 90s, but their banking systems are still competitive (see Demirguc-Kunt and Huizinga, 1998).
} 
that regulation plays a crucial role in delivering competition, particularly in the telecommunications sector, we add a third element-the nature of regulation--in constructing the index for the telecommunications sector. ${ }^{11}$ Since data on the quality of financial regulation was unavailable at the time the exercise was undertaken, we added current and capital account openness (instead of regulation) as the third element of the liberalization index for financial services. ${ }^{12}$ And in recognition of the argument (advanced forcefully by Rodriguez and Rodrik (1999)), that any measure of liberalization should reflect policy variables rather than outcomes, we avoid the use of ex post indicators such as teledensity (in the case of the telecommunications sector), or the degree of monetization of an economy (for financial services). ${ }^{13}$

An advantage of our index construction approach is that, in ranking various alternative policy combinations, it gives credit to adoption of partial liberalization measures. However, the disadvantage of ranking countries by various policy combinations and pre-supposing competition to be more important than foreign ownership (or regulation, say) is that it imposes a constraint on the data. A further constraint on the data is imposed by the cardinality of the index, i.e., according to our index, the benefit of going from a situation of competition and private ownership, but no independent regulator to a situation with all three elements, is the same as that arising from moving from a situation with monopoly, independent regulation, but no foreign ownership to a situation of monopoly, private ownership and independent regulation.

Our second approach is motivated by the consideration that sometimes, partial liberalization may not bring about significant benefits. For example, privatizing or introducing foreign ownership without introducing competition (or establishing a separate regulator), would simply transfer monopoly rents from the government to

\footnotetext{
${ }^{11}$ It should be noted that regulation fosters competition in two ways: first, it is necessary for new entrants to a market to have equitable access to certain essential facilities provided by the incumbent. Second, even in the absence of competition, regulation can in principle force a monopolistic supplier to behave more competitively. While regulation plays an important, indeed key role, in the overall efficiency of the financial services sector, its main role is prudential rather than to foster competition.

${ }^{12}$ Barth, Caprio and Levine (2001) have created a new database on bank regulation and supervision. The task of developing an index of the quality of banking regulation using information from this database should be undertaken.

${ }^{13}$ Baldwin (1989) first emphasized the distinction between policy-based and outcome-based measures, and also contains an exhaustive discussion of the various methods of measuring non-tariff trade measures.
} 
the private monopolist. Hence, we create dummy variables to test for the benefits of moving from partial, or no liberalization, towards full liberalization. Full liberalization is defined in relation to the same elements of liberalization (competition, ownership and regulation/capital controls) that we used for index construction as explained above. Hence, we consider the telecom sector fully liberalized only if competition is introduced, FDI is allowed, and if an independent regulator exists. Similarly, the financial sector is fully liberalized according to our criteria, only if the banking sector is competitive/open to entry, majority foreign ownership is allowed, and current and capital account transactions are liberalized. Partial liberalization is interpreted as a situation where one or two of these elements is missing, and cases where none of the elements is present is regarded as no liberalization. This approach does not impose prior restrictions on the data, in terms of the relative importance of the three criteria, and merely tests for the gains emanating from full liberalization.

\section{A. Openness Indicator for the Telecommunications Sector}

For basic telecommunications, the challenge was to integrate the three key aspects of policy identified above-namely, competition, foreign ownership, and regulation--into an index. Recent empirical work on the impact of policy changes on telecommunications performance, suggests that "competition is the most effective agent of change, privatization without regulation may not improve service, and regulation is especially important when privatizing a monopoly incumbent" (Wallsten, 1999). Further research on 12 developing East Asian countries' telecom sectors by Fink, Mattoo and Rathindran (2001) finds positive evidence on the interaction of competition and privatization. Similarly, while foreign direct investment is bound to bring significant benefits, for instance through the transfer of technology and the improvement of management, the absence of competition and effective regulation may dilute these benefits. Finally, the existence of a regulator serves not only to impose discipline on the final price in the absence of competition, but is also needed to promote effective competition, by ensuring access for rival service suppliers to the networks of incumbents on reasonable terms.

We create an index of liberalization (ranging from 1 to 9 , with higher values signifying greater liberalization). The index has a lexicographic character: competition is deemed to be the most important element of policy followed by foreign ownership and then by regulation. ${ }^{14}$ Thus a regime in which competition is 
allowed is ranked higher than one in which it is not, irrespective of the treatment of foreign investment and regulation. The latter aspects become relevant in ranking two regimes which are identical in terms of the degree of competition allowed. The most liberal value of the index arises when there is competition between providers, no restrictions on FDI and an independent regulator, and the most protected situation is a monopoly with foreign ownership prohibited and no independent regulator (Annex 2 presents details on the construction of the index, and figure 1, its values for different countries). The data comes from a recently-created World Bank-ITU database on policy in the telecommunications sector.

From this information, we are also able to create a dummy variable for complete or full openness in telecommunications. The dummy variable for complete liberalization of telecom takes the value 1 only if a country allows competition in the local, long distance and international calling segments, allows FDI, and has an independent telecom regulator. The variable takes the value zero if even one of the three above elements is lacking. In other words, the dummy variable takes the value 1 for all those countries that received a ranking of 1 according to the index described earlier, and takes the value zero for all other countries. ${ }^{15}$

\section{B. Openness indicator for the Financial Services Sector}

The openness indicator for the financial services sector is constructed on the same principles as that for the telecommunications sector. There were, however, three important differences. First, we did not have data on the national policies relating to competition and foreign ownership in financial services but inferred them from individual countries' commitments under the General Agreement on Trade in Services. These commitments bear a close resemblance to actual policy (Mattoo, 1999). Secondly, we are not able to capture the regulatory dimension because of the lack of comparable data across countries. ${ }^{16}$ Regulation in this sector does not have the same competition promoting role that it does in the telecommuni-

\footnotetext{
${ }^{14}$ We use market structure data from a 1998 I.T.U. survey. The competition variable represents observed market structure. However, it is well known that in most countries, the number of basic telecom operators is fixed by policy, making observed and allowed market structure equivalent. See for example Fink et al. (2001)

${ }^{15}$ This approach is similar in spirit to the construction of the openness dummy variable in Sachs and Warner (1995), where a country had to satisfy 5 criteria before it could be classified as being open.

${ }^{16}$ As mentioned earlier, developing an index of regulatory quality from Barth, Caprio and Levine's (2001) database should be on the cards.
} 
cations sector, but the omission may nevertheless be serious because the quality of banking and prudential regulation is of paramount importance in addressing systemic risk.

We do, however, make an effort to capture the openness of a country's current and capital account because this has a bearing both on the possibility of crossborder trade in financial services and the conditions for establishing foreign

Figure 1. Openness indices by country

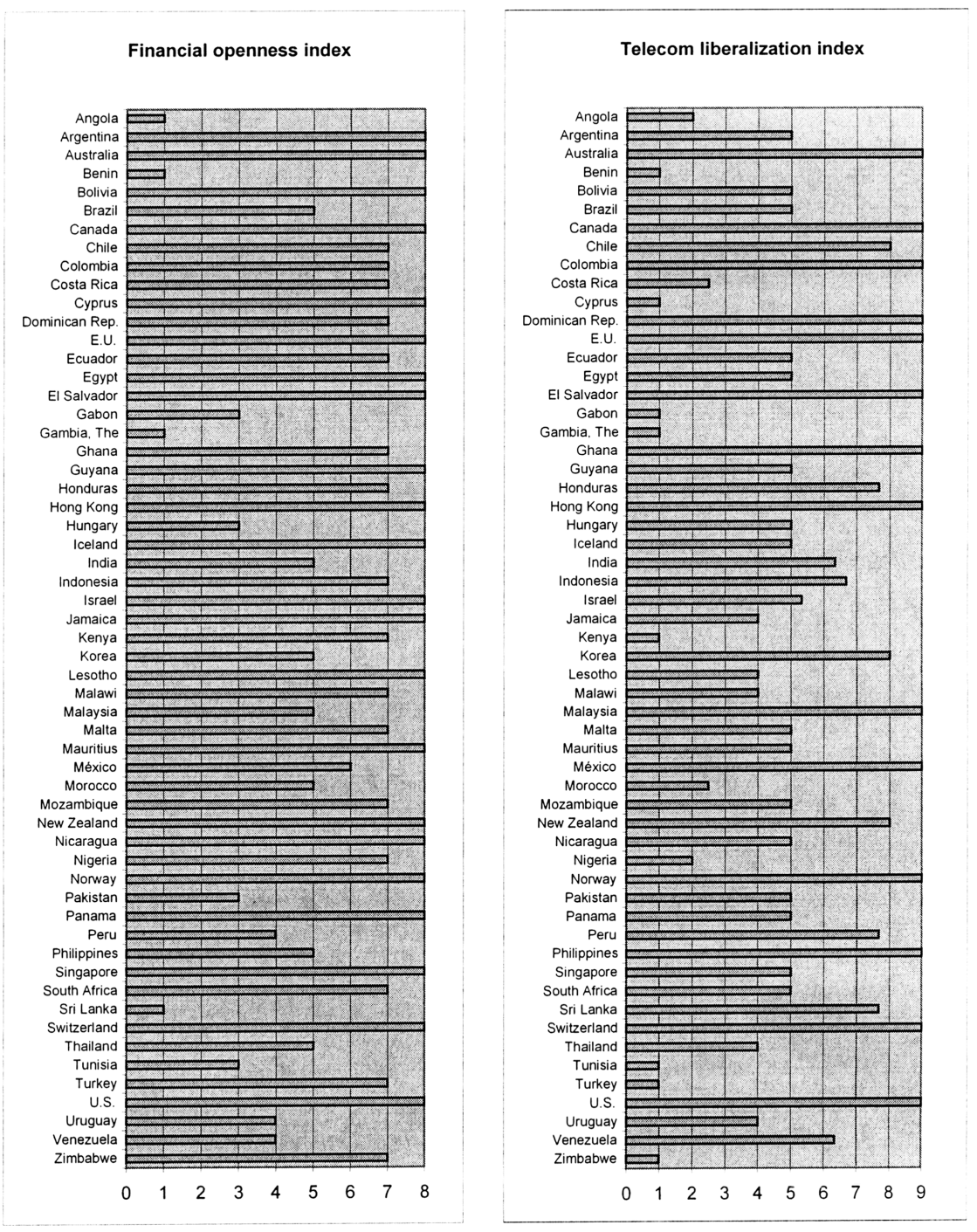

Source: World Bank Services Database 
commercial presence. For this purpose, we use the index of capital controls compiled by Dailami (2000) using information from the Annual Report on Exchange Arrangements and Exchange Restrictions published by the I.M.F.

We combine these policy elements into an index for openness to financial services trade (ranging from 1 to 8 ) with higher values of the index indicating more financial openness. This index has the virtue of being a combination of exogenous policy measures. Annex 3 presents a more detailed explanation of the methodology. For individual country rankings, please refer to the second column of Annex 4. The informed reader may notice some peculiarities in the rankings. For example, Brazil, Indonesia, Thailand and Colombia receive very illiberal rankings in terms of the criteria we inferred from GATS commitments. However, despite not having committed to open entry in the GATS, these countries have allowed entry in the past as can be seen if one examined their bank concentration ratios, or the share of foreign banks in total number of banks. In order to correct for such paradoxes, and as a robustness check in our regressions, we adjust the financial services liberalization index upward (i.e., assign more liberal rankings) for those countries that show low levels of bank concentration, and a relatively high share of foreign banks in total number of banks, but had initially received an illiberal ranking. ${ }^{17,18}$ To see how the rankings change once this is done, refer to the third column of Annex $4 .{ }^{19}$ To get a sense of how countries ranked in terms of our openness indices, refer figure 1.

The dummy variable for complete liberalization of financial services takes the value 1 only if the banking sector is competitive, majority foreign equity is allowed, and if the country has a value of 1.6 or more on the Dailami index of capital controls, and is zero, otherwise. ${ }^{20}$ Alternatively, the dummy variable takes the value 1 for all those countries that received a ranking of 1 according to the

\footnotetext{
${ }^{17} \mathrm{We}$ considered the market competitive if the concentration ratio for the three largest banks was 0.5 or below, i.e., if the three largest banks accounted for 50 per cent or under of total banking sector assets. Data on concentration ratios was obtained from Beck, Demirguc-Kunt and Levine's database on Financial Development and Structure.

${ }^{18}$ We interpreted openness to foreign bank entry as having a foreign bank penetration rate of over 0.2 , i.e., if there share of foreign banks in the total number of banks was 20 per cent or over. Again, the data were obtained from Beck, Demirguc-Kunt and Levine's database.

${ }^{19}$ We do not however, adjust the index downward for countries that made open entry commitments in the GATS, but have high levels of bank concentration and low foreign bank penetration, as the commitments on open entry reflect a liberal policy stance, making their banking markets contestable despite the presence of only a few banks in the market.

${ }^{20}$ Dailami considers countries that score 1.6 or more (on his index) open, and the rest closed.
} 
index of financial services liberalization, and is zero, otherwise. We also construct a dummy variable representing those countries that had fully liberalized both sectors. It takes the value 1 if both telecom and financial services are fully liberal and is zero otherwise. It could been seen as the product of the dummy variables for full liberalization in telecom and full liberalization in financial services.

\section{Empirical Evidence}

We run cross-country regressions for a sample of 60 countries for the period 1990-1999. ${ }^{21}$ Our regression specification is given below:

$$
G_{j}=\alpha+\beta X_{j}+\gamma R_{j}, \text { for } j=1 \ldots \ldots . N
$$

Where $G_{j}$, our dependent variable, is the average annual growth rate of per capita GNP between 1990 and 1999 in country $j, a$ is the constant term, $X_{j}$ is the vector of standard growth controls for country $j, R j$ is a vector of the openness to trade in services for country $j$ and $N$ represents the number of countries in our sample. ${ }^{22}$

The standard growth controls include the natural log of per-capita GNP in 1990 (the convergence variable), a lagged value of the investment rate, the government consumption to GDP ratio to proxy for the size of the government and government induced distortions, the inflation rate (which serves as a proxy for macroeconomic imbalances), a proxy variable for political stability, an index representing the quality of institutions, geographical and regional dummies, a schooling ratio, and an index of tariff and non-tariff barriers. ${ }^{23}$ The data for per capita GNP (evaluated at purchasing power parity), the investment rate, the government consumption to

\footnotetext{
${ }^{21}$ The choice of sample period was dictated by two considerations. Firstly, the period should be sufficiently long to allow meaningful inferences about long run growth performance. Secondly, since services sector liberalization is quite recent, we could not go too far back. In fact, most of our policy data pertains to the last few years. It is assumed that our indices approximate cross-country variation in the degree of protection of the services sectors for the entire period 1990-1999. Our results may suffer from a downward bias since some slow-growing African countries have received a fairly liberal ranking even though they were closed during much of the 1990s but opened up in recent years.

${ }^{22}$ In accordance with most growth studies, we used the GNP adjusted for purchasing power parity. The average annual rate of growth was calculated by $\left[\left(\ln G N P_{t+n}-\ln G N P_{t}\right) / \mathrm{n}\right]$, which is a fairly standard practice in cross-country growth studies.

${ }^{23}$ The index representing the quality of institutions is compiled using information from the International country risk guide. For more on the index, see Keefer and Knack (1995).
} 
GDP ratio, the inflation rate, and the primary education enrollment rate were obtained from the World Development Indicators database at the World Bank. The geographical and regional variables include dummy variables for tropical countries, Sub-Saharan Africa, Latin America and East Asia, and are constructed as in Sachs Warner (1995), Edwards (1993) and Dollar (1992). Paraguay and Ireland are treated as outliers and excluded from the regressions presented here. ${ }^{24}$ The proxy for political stability and the index of institutional quality are from Sachs and Warner (1995). The tariff and non-tariff barriers index was obtained from the IMF. ${ }^{25}$

\section{A. Testing the significance of indices of liberalization.}

The results from the estimation that include the telecom and financial services trade liberalization indices are presented in Table 3. Columns 1-3 pertain to the whole sample, while the regression in column 4 includes only the 37 developing countries in the sample. The results suggest that both the extent of financial and telecom sector liberalization contribute meaningfully to explaining cross-country GNP growth performance. In the context of the discussion in section II, this in turn suggests that the productivity enhancing effect and the increased scale of activity arising from liberalization more than compensate for any fall in the employment of nationally owned factors of production. As evident from the table, the coefficient on the financial sector index is consistently positive as expected, and significant at the 5 per cent level in all cases, even after controlling for the usual determinants of growth. The telecommunications liberalization index is also consistently positive, stable, and significant, albeit at the 10 per cent level in the regressions that included regional dummies. The magnitudes of the coefficients are also fairly stable. The magnitude of the coefficients on the indices is much higher for developing countries. All growth controls but one appear with their expected signs. ${ }^{26}$ For partial scatter plots of growth against the liberalization indices after controlling for other factors, see Figures $2 \mathrm{a}$ and $2 \mathrm{~b}$ below. ${ }^{27}$

\footnotetext{
${ }^{24}$ Paraguay and Ireland were identified as outliers from the DFBETA statistic. On observation "i" may be considered an outlier if $\mid$ DFBETAi $\mid>2 / \sqrt{N}$, where $N$ represents the number of observations.

${ }^{25}$ The index takes values from 1-10 with higher values being indicative of more protection. For more, refer Sharer et. al.

${ }^{26}$ The proxy for political stability appears with the wrong sign in some regressions, but is insignificant. The index of institutional quality is also insignificant, and is wrongly signed in a few of the regressions presented later. ${ }^{27}$ Please note that the scatters correct the x-axis for collinearity with other regressors, so that the positions
of countries in the graph are not the original data points.
} 
Figure 2a. Relationship between Financial Figure 2b. Relationship between telecoLiberalization and Growth mmunications liberalization and growth
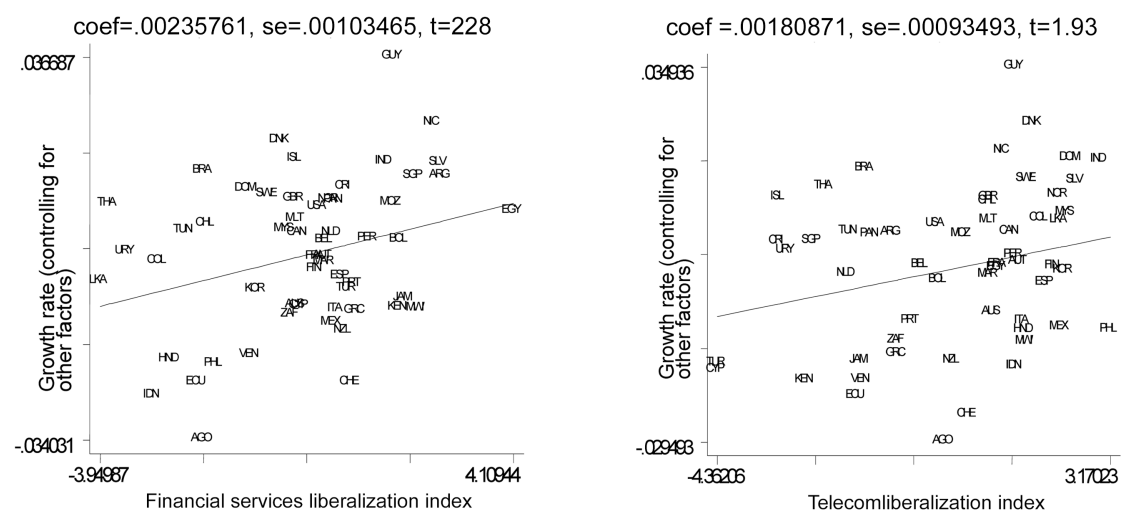

As an alternative exercise, we construct a composite index of services trade liberalization by taking the simple average of the telecom and financial services indices. The results are presented in Table 4. As before, columns 1-3 are for the whole sample, and column 4 , for only developing countries. The composite index is extremely significant, at the 1 per cent level in the regressions without regional dummies and at the 5 per cent level in those with regional dummies and the regression for developing countries. Its estimated coefficient is remarkably stable and approximately the sum of the coefficients on the telecom and financial services indices obtained from introducing the indices separately as done in Table 3. The partial scatter of growth and the composite index after controlling for other factors is depicted in Figure 3.

Figure 3. Relationship between services liberalization and growth

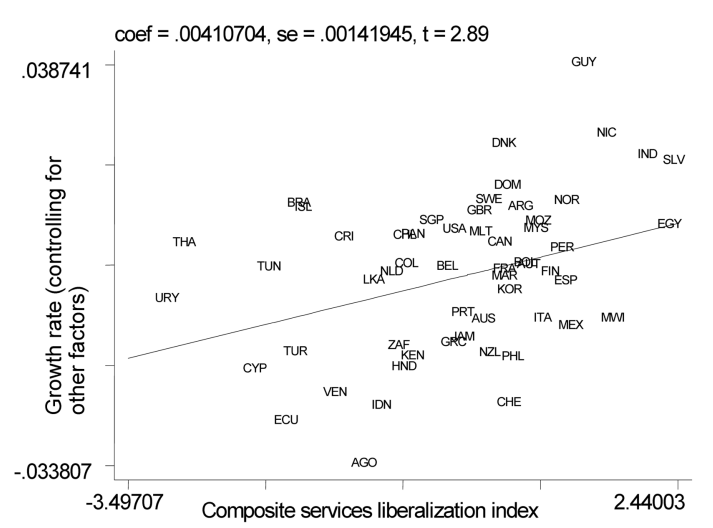


We also test for the significance of the financial services index corrected for observed market structure and foreign bank penetration. We run regressions similar to the ones in Tables $3 \& 4$ and find the results to be broadly similar. Table 5 shows that the financial services liberalization index is still positively correlated with, and a significant predictor of growth over the $90 \mathrm{~s}$. The telecom liberalization index is also appears positively significant at the 10 per cent level in one case and at the 5 per cent level in the other. Column 3 of Table 5 shows that the composite index (reconstructed after adjusting the financial openness index) is a highly significant predictor of growth.

\section{B. Testing for benefits of complete liberalization}

The results using dummies for full liberalization are presented in Table 6. After controlling for other determinants of growth, it is seen from column 1 that for the whole sample, complete liberalization in the financial services sector has a significantly (at the 1 per cent level) positive impact on growth. The dummy variable for complete liberalization of telecom also has a positive and significant (at the 10 per cent level) coefficient. Columns 3 and 4, which only includes developing countries, features both dummy variables being positively significant influences on growth at the 5 per cent level.

As a measure of complete liberalization of both sectors, we interact the liberalization dummies of telecom with financial services so that the variable takes the value 1 if both sectors are completely liberal in a given country, and zero otherwise. This variable is also found to exert a significantly positive influence on growth in the 90 s as seen in columns 1 and 2 of Table 7 for our whole sample, and columns 3 and 4 for developing countries only. The coefficient estimate of .015 on the dummy for complete liberalization in both sectors seems to suggest that countries that fully liberalized both telecom and financial services grew up to 1.5 percentage points faster than others over the 90s. However, this estimate needs to be qualified keeping in mind the limitations of the data, cross-country estimation, and due to the fact that it might be capturing one-shot gains since the liberalization variables are constructed using information from the latter half of the 1990s. ${ }^{28}$ Another interesting observation from the results is that the magnitudes of the coefficients on the liberalization indices is much higher for the regressions run over only developing countries. This suggests that services liberalization could bring greater growth benefits to developing countries.

Finally, it is worth noting that the estimated coefficient on the IMF trade 
restrictiveness index is also stable and statistically significant. ${ }^{29}$ On a priori grounds, we expected the impact of services liberalization on growth to be greater than that of goods liberalization. Yet, in the regressions, the I.M.F. index outperforms the telecom and financial services indices in terms of the magnitude and level of significance of its estimated coefficient. We believe this could be because the services indices represent individual services sectors whereas the goods trade restrictiveness index is an aggregate index for the primary and manufacturing sectors. When the composite services index is used in a regression with the IMF index, the magnitude of the estimated coefficient on the former is higher and the significance levels are comparable.

\section{Conclusion and Further Research}

The paper had three objectives. First, it attempted to explain why and how the impact of services liberalization on output growth differed from that of goods liberalization. Second, it proposed a possible measure of the openness of a country's services regime, and constructed such measures for two key service sectors, basic telecommunications and financial services. Finally, in order to test whether the openness of the policy regime in services had an impact on long run economic growth, these openness measures were introduced in cross-country growth regressions à la Barro and Sachs and Warner.

We reach three broad conclusions. First, services liberalization is different from trade in goods because the former necessarily involves factor mobility and leads to scale effects that are distinctive though not unique. Together these can have important positive effects on long run economic growth.

Second, it is possible to construct policy-based rather than outcome-based measures of openness for the services sectors that capture these differences. Unlike

\footnotetext{
${ }^{28}$ As previously mentioned, Verikios and Zhang have estimated the global gains from liberalizing trade in telecommunications and financial services using an FTAP (Foreign Direct Investment and Trade Analysis Project) model developed at the Australian Productivity Commission. Their estimates suggest that the removal of barriers to trade in telecommunications and financial services is projected to increase the level of world real GNP by about 0.2 per cent. According to them, most of the gains from telecommunications liberalization come from the removal of non-discriminatory barriers, whereas most of the gains from financial services liberalization come from the elimination of discriminatory barriers.

${ }^{29}$ Unlike the openness variable in Sachs and Warner (1995), the IMF index captures only trade policy variables, and is therefore invulnerable to one of the Rodriguez and Rodrik criticisms of the SachsWarner variable, namely that their openness dummy is a proxy for macroeconomic policy imbalances.
} 
in trade in goods where the policy openness measure needs to capture only the openness to foreign supply, in the case of services openness measures must capture both the policy regime toward inward flows of foreign factors and measures that promote domestic competition.

Third, there is some econometric evidence-relatively strong and robust for the financial sector and less strong but nevertheless statistically significant for the telecommunications sector-that openness to trade in services influences long run growth performance. Our estimates suggest that countries with fully open telecom and financial services sectors grow up to 1.5 percentage points faster than other countries. These results, however, need to be refined by incorporating more information in the construction of indices of openness and testing whether they hold for other services sectors.

There remains considerable scope for refining and elaborating on this study. At the very least, the exercise would need to cover other important service sectors such as transportation as well as other financial sub-sectors such as insurance and securities. ${ }^{30}$ Second, the quality of the openness indices needs to be refined both by using better data (such as panel data) and improving our understanding of how different elements of policy-measures affecting entry, foreign investment and regulation-interact in different services sectors.

\section{Acknowledgements}

The authors would like to thank Bernard Hoekman, Aart Kraay, Will Martin, Marcelo Olarreaga, Maurice Schiff and Aristomene Varoudakis for helpful comments. This paper is part of the World Bank's research program on trade in services, which is supported in part by a grant from the United Kingdom's Department for International Development. Thanks are also due to Malina Savova for providing excellent research assistance. The views expressed in the paper do not necessarily reflect those of the institutions with which the authors are associated. Errors and excesses remain our own.

Received 23 July 2003, Accepted 19 April 2005

\footnotetext{
${ }^{30}$ Barth, Caprio and Levine (2000) have conducted extensive cross-country studies on the relationship between commercial bank regulation on the one hand and banking sector performance and financial stability on the other. They incorporate information about permitted activities of commercial banks (for example, insurance, securities, real estate and non-financial firm ownership).
} 


\section{References}

Baldwin, Robert E. (1989) Measuring Non-Tariff Trade Policies, Working Paper No. 2978, NBER Working Paper Series, Cambridge, MA.

Barth, James R., Gerard Caprio Jr., and Ross Levine (2001) The Regulation and Supervision of Banks Around the World: A New Database, Policy Research Working Paper 2588, Development Research Group, World Bank.

Barth, James R., Gerard Caprio Jr., and Ross Levine (2000) Banking Systems Around the Globe: Do Regulation and Ownership Affect Performance and Stability, Policy Research Working Paper 2325, Development Research Group, World Bank.

Barro, Robert J. (1997) Determinants of Economic Growth: A Cross-Country Empirical Study, Cambridge, MA, MIT Press.

Barro, Robert J. and Jong-Wha Lee (1997) Losers and Winners in Economic Growth, Proceedings of the World Bank Annual Conference on Development Economics, World Bank.

Beck, Thorsten, Asli Demirguc-Kunt and Ross Levine (1999) A New Database on Financial Development and Structure, Policy Research Working Paper 2146, Development Research Group, World Bank.

Ben-David, Dan (1993) Equalizing Exchange: Trade Liberalization and Economic Convergence, Quarterly Journal of Economics, 108(3).

Borenzstein, E., J. D. Grigorio and J. W. Lee (1998) How Does Foreign Direct Investment Affect Economic Growth?, IMF Working Paper, Washington, D.C.

Braga, Carlos A. Primo, Liberalizing Telecommunications and the Role of the World Trade Organization, Public Policy for the Private Sector, Note 120.

Claessens, Stijn and Tom Glassner. (1998) The Internationalization of Financial Services in Asia, Policy Research Working Paper No. 1911, World Bank, Washington D.C.

Claessens, Stijn, Asli Demirguc-Kunt and Harry Huizinga (1998) How Does Foreign Entry Affect the Domestic Banking Market?, Policy Research Working Paper 1918 (revised), World Bank.

Claessens, Stijn and Daniela Klingebiel (1999) Alternative Frameworks for the Provision of Financial Services: Economic Analysis and Country Experiences, Policy Research Working Paper 2189, World Bank.

Coe, David T. and Alexander W. Hoffmaister (1997) North-South R \& D Spillovers, The Economic Journal (U.K.), 107, 134-39.

Collier, Paul, and J.W. Gunning (1999) Why has Africa grown slowly, Journal of Economic Perspectives (U.S.), 13(3), 3-22.

Dailami, Mansoor (2000) Financial Openness, Democracy and Redistributive Policy, mimeo, World Bank Institute.

Deardorff, Alan V. (2001) International Provision of Trade Services, Trade, and Fragmentation, Review of International Economics, 9(2), 233-248.

Demirguc-Kunt, Asli and Harry Huizinga (1998) Determination of Commercial Bank 
Interest Margins and Profitability: Some International Evidence, Policy Research Working Paper 1900, World Bank.

Dollar, David (1992) Outward-Oriented Developing Economies Really Do Grow More Rapidly: Evidence from 95 LDCs, 1976-85, Economic Development and Cultural Change.

Edwards, Sebastian (1993) Openness, Trade Liberalization, and Growth in Developing Countries, Journal of Economic Literature, XXXI (3).

Francois, J.F. and Ludger Schuknecht (1999) Trade in Financial Services: Procompetitive Effects and Growth Performance, CEPR Discussion paper 2144.

Frankel, Jeffrey A. and David Romer (1999) Does Trade Cause Growth?, American Economic Review.

Fink, Carsten, Aaditya Mattoo, and Randeep Rathindran (2002) Liberalizing Basic Telecommunications: The Asian Experience, HWWA-Institut für Wirtschaftsforschung Discussion Paper 163.

Goldsmith, Raymond W. (1969) Financial Structure and Development, Yale University Press, New Haven.

Grossman, Gene and Elhanan Helpman (1991) Innovation and Growth in the Global Economy, M.I.T. Press.

Hoekman, B. and C. Primo Braga (1997) Protection and Trade in Services: A Survey, Open Economies Review, 8, 285-308.

Hoekman, B. and Simeon Djankov (1997) Effective Protection and Investment Incentives in Egypt and Jordan: Implications of Free Trade With Europe, World Development, 25, 281-91.

Keefer, Philip and Steven Knack (1995), Institutions and Economic Performance: CrossCountry Tests Using Alternative Measures, Economics and Politics, 7, 207-227.

King, Robert G., and Ross Levine (1993b), Finance, Entreprenneurship and Growth: Theory and Evidence, Journal of Monetary Economics, XXXII.

Levine, Ross (1997), Financial Development and Economic Growth: Views and Agenda, Journal of Economic Literature.

Mattoo, Aaditya (1999), Financial Services and the WTO: Liberalization Commitments of the Developing and Transition Economies, Policy Research Working Paper No. 2184, Development Research Group, World Bank.

Mattoo, Aaditya and Ludger Schuknecht (1999) Explaining Liberalization Commitments in Financial Services Trade, mimeo, World Bank.

Rodriguez, Fransisco and Dani Rodrik (1999) Trade policy and Economic Growth: A Skeptic's Guide to the Cross-National Evidence, Discussion Paper 2143, Center For Economic Policy Research.

Sachs, Jeffrey D. and Andrew Warner (1995) Economic Reform and the Process of Global Integration, Brookings Papers on Economic Activity, 1995, 1.

Sachs, Jeffrey D. and Andrew Warner (1997) Fundamental Sources of Long-Run Growth, American Economic Review, Papers and Proceedings, 87(2), 184-88.

Sharer, Robert et. al (1998) Trade Liberalization in IMF-Supported Programs, World 
Economic and Financial Surveys, International Monetary Fund.

Summers, Lawrence (1999) Reflections on Managing Global Integration, Journal of Economic Perspectives (U.S.), 13, 3-18.

Verikios, George, and Xiao-guang Zhang (2001) Global Gains from Liberalizing Trade in Telecommunications and Financial Services, Productivity Commission Staff Research Paper, AusInfo, Canberra.

Vives, Xavier (1998) Competition and Regulation in European Banking, Chapter 8 in Stijn Claessens and Marion Jansen (eds) Internationalization of Financial Services: Issues and Lessons for Developing Countries, Kluwer Academic Press.

Wallsten, Scott J. (1999) Competition, Privatization, and Regulation in Telecommunications Markets in Developing Countries: An Econometric Analysis of Reforms in Africa and Latin America, Policy Research Working Paper No. 2136. 


\section{Annex 1. An Illustration of the gains from services liberalization}

Gains from reduction in Transport Costs

Figure 4.

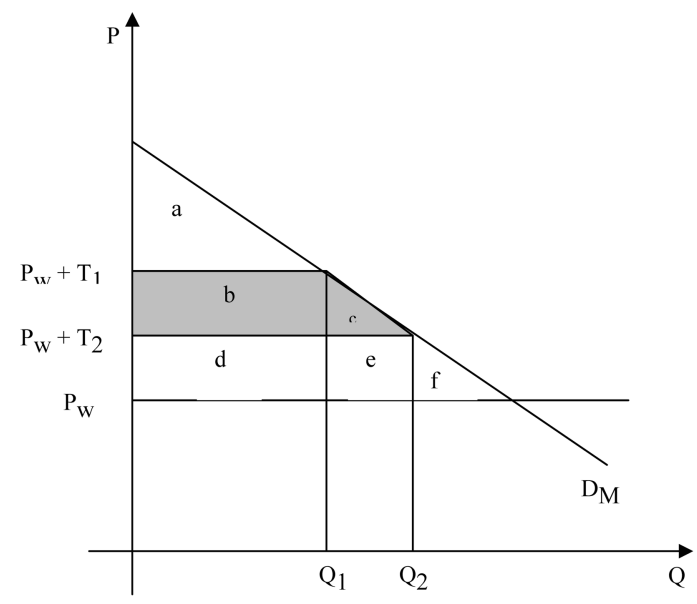

In Figure 4 above, the importing country takes the world price of the good $(P w)$ as given and $D M$ is the demand for imports. Assuming a transport cost $(T 1)$, the price facing the importing country will be $P w+T 1$. If as a result of the liberalization of maritime transport services, the transport cost falls to $T 2$, then the import price drops to $P w+T 2$. The area $b+c$ represents welfare gains to the importing country due to an increase in consumer surplus, consisting of not only the triangle $c$ (formerly a deadweight loss), but also the rectangle $b$ of gains from reduced transport costs.

\section{Annex 2. Methodology for Constructing Telecom Index of Openness}

The telecommunications openness index was constructed using information on the market structure in basic telecom, whether FDI is allowed and whether an institutionally independent telecom regulator was in place. Information on these elements was obtained from the International Telecommunications Union (ITU). We assigned ranks based on a lexicographic scheme shown in the table below. 
Table 1. Structure of Telecommunications Liberalization Index

\begin{tabular}{cccc}
\hline INDEX & Market structure & Ownership (FDI) & Independent regulator \\
\hline VALUE & Competitive & FDI allowed & Yes \\
8 & Competitive & FDI allowed & No \\
7 & Competitive & FDI not allowed & Yes \\
6 & Competitive & FDI not allowed & No \\
5 & Not Competitive & FDI allowed & Yes \\
4 & Not Competitive & FDI allowed & No \\
3 & Not competitive & FDI not allowed (private) & Yes \\
2 & Not competitive & FDI not allowed (public) & Yes \\
1 & Not competitive & FDI not allowed & No \\
\hline
\end{tabular}

So for example, Cote d'Ivoire, which has a monopoly in its local, domestic long distance and international call segments, with 100 per cent FDI allowed and an independent regulator, gets a rank of 5 according to our scheme.

A complication arises from the definition of "the market." Does it refer to international calls or domestic long distance telephony or to local calls? Market structures and ownership regulations typically are not uniform across these market segments. Where there is variation across these segments we computed the weighted average with all segments receiving equal weight.

For example, in the case of Poland, the local segment is competitive, but the domestic long distance and international segments are a monopoly. It allows 49 per cent FDI and does not have an independent regulator. Poland would get a rank of 8 in our scheme if all segments were competitive and a rank of 4 if all segments were uncompetitive. In our view, the best measure was to take a weighted average of the two ranks accounting for the fact that there are two uncompetitive segments (domestic long distance and international calling) and only one competitive segment (local calling). So the weighted rank for Poland would be:

$$
(1 / 3 * 8)+(2 / 3 * 4)=5.33
$$

For a detailed description of how the countries in our sample ranked in terms of openness in their telecom sectors, refer to Annex 4. 


\section{Annex 3. Methodology for Computing Financial Services Index of Openness}

The construction of the financial services index is similar in spirit to that of the telecom index explained previously. We focused on domestic market structure, foreign ownership, and ease of cross-border trade in the banking sector. The information on banking competition policy and foreign ownership was obtained from the financial services commitments ${ }^{31}$ contained in the GATS and adapted from Mattoo (1998). These can be interpreted as capturing the policy stance on Mode 3 (commercial presence, or establishment trade in financial services).

In order to capture the policy stance on cross border trade (mode 1 according to the GATS) in financial services, we thought it appropriate to include information on current and capital account restrictions. Indeed, unrestricted flows on the current and capital account are necessary for cross-border trade in financial services. For example, if a domestic company wants to borrow abroad and use the services of a foreign financial services company, there must not be restrictions on foreign borrowing (capital account) nor on payments for financial services rendered by the foreign company (current account).

To capture the ease of such cross-border trade, we used an index constructed by Dailami (2000) using information from the I.M.F's Annual Report on Exchange Arrangements and Exchange Restrictions. It is a composite index based on a coding of rules, regulations, and administrative procedures affecting capital flows for a total of 27 individual transactions in the current and capital account of the balance of payments for each country ${ }^{32}$. Higher values of Dailami's index are indicative of greater financial openness of cross-border trade. As evident from Dailami's index, the broadly open countries (in terms of having fewer restrictions on the current and capital account transactions) are ones for which the Dailami index has a value of 1.6 or more, and the closed ones have a value below the 1.6 cut off. Hence we implicitly defined openness to cross-border trade according to whether a country's rating on the Dailami index was greater or less than 1.6.

In interpreting a country's GATS financial services commitments relating to market structure, an entry of "unbound" or "discretionary licensing" was deemed

\footnotetext{
${ }^{31}$ Since not all countries have made GATS commitments in financial services, we are automatically restricted to the countries that did by the mid 1990s. For the telecom sector, the information from the ITU spanned a much larger number of countries.

${ }^{32}$ For more information, see Dailami (2000).
} 
to be an "uncompetitive" market, whereas an entry of "none" was taken to imply the existence of a competitive environment. We created the financial services index using a lexicographic method giving priority to market structure followed by openness to FDI and then by ease of cross-border trade (see table below).

Table 2. Structure of Financial Liveralization Index

\begin{tabular}{cccc}
\hline $\begin{array}{c}\text { INDEX } \\
\text { VALUE }\end{array}$ & Market structure & $\begin{array}{c}\text { FOREIGN EQUITY } \\
\text { PERMITTED }\end{array}$ & $\begin{array}{c}\text { CAPITAL CONTROLS } \\
\text { (Dailami) INDEX }\end{array}$ \\
\hline 8 & Competitive & $\geq 50$ per cent & $\geq 1.6$ \\
7 & Competitive & $\geq 50$ per cent & $<1.6$ \\
6 & Competitive & $<50$ per cent & $\geq 1.6$ \\
5 & Competitive & $<50$ per cent & $<1.6$ \\
4 & Not Competitive & $\geq 50$ per cent & $\geq 1.6$ \\
3 & Not Competitive & $\geq 50$ per cent & $\geq 1.6$ \\
2 & Not competitive & $<50$ per cent & $<1.6$ \\
1 & Not competitive & $<50 \%$ per cent &
\end{tabular}

Hence, a higher score on our index denotes greater openness to trade in financial services than does a lower score. For a complete description on how countries ranked in terms of financial sector openness, refer to Annex 4.

\section{Annex 4. Liberalization Indices by Country}

\begin{tabular}{ccccc}
\hline COUNTRY NAME & $\begin{array}{c}\text { (Fin. Lib. } \\
\text { INDEX) }\end{array}$ & $\begin{array}{c}\text { Fin. lib. } \\
\text { Index } \\
\text { (adjusted) }\end{array}$ & Country Name & $\begin{array}{c}\text { (Telecom } \\
\text { lib. index) }\end{array}$ \\
\hline Angola & 1 & 1 & Algeria & 1 \\
Brazil & 1 & 5 & Benin & 1 \\
Gambia, The & 1 & 1 & Burkina Faso & 1 \\
Pakistan & 1 & 3 & Cameroon & 1 \\
Benin & 1 & 1 & Gabon & 1 \\
Sri Lanka & 1 & 1 & Gambia, The & 1 \\
Thailand & 1 & 5 & Kenya & 1 \\
Indonesia & 2 & 7 & Liberia & 1 \\
Colombia & 3 & 7 & Mali & 1 \\
Gabon & 3 & 3 & Niger & 1 \\
Tunisia & 3 & 3 & Sierra Leone & 1 \\
Dominican Rep. & 3 & 7 & Swaziland & 1 \\
Hungary & 3 & 3 & Zimbabwe & 1 \\
\hline
\end{tabular}




\begin{tabular}{|c|c|c|c|c|}
\hline COUNTRY & $\begin{array}{c}\text { FINANCIAL } \\
\text { LIBERAL- } \\
\text { IZATION } \\
\text { INDEX }\end{array}$ & $\begin{array}{c}\text { FINANCIAL } \\
\text { LIBERALIZA- } \\
\text { TION INDEX } \\
\text { (adjusted) }\end{array}$ & $\begin{array}{c}\text { COUNTRY } \\
\text { NAME }\end{array}$ & $\begin{array}{c}\text { TELECOM } \\
\text { LIBERAL- } \\
\text { IZATION } \\
\text { INDEX }\end{array}$ \\
\hline United Arab Emirates & 3 & 3 & Turkey & 1 \\
\hline Ecuador & 3 & 7 & Togo & 1 \\
\hline Honduras & 3 & 7 & Tunisia & 1 \\
\hline Nicaragua & 4 & 8 & Iran, Islamic Rep. & 1 \\
\hline Peru & 4 & 4 & Syrian Arab Republic & 1 \\
\hline Philippines & 4 & 5 & Cyprus & 1 \\
\hline Mauritius & 8 & 8 & Myanmar & 1 \\
\hline Uruguay & 4 & 4 & Angola & 2 \\
\hline Venezuela & 4 & 4 & Nigeria & 2 \\
\hline India & 5 & 5 & Papua New Guinea & 2 \\
\hline Malaysia & 5 & 5 & Ethiopia & 2.5 \\
\hline Morocco & 5 & 5 & Morocco & 2.5 \\
\hline Bahrain & 6 & 6 & Costa Rica & 2.5 \\
\hline Chile & 5 & 7 & Bangladesh & 2.67 \\
\hline Korea & 5 & 5 & Cape Verde & 3 \\
\hline México & 6 & 6 & Central African Republic & 4 \\
\hline Malawi & 7 & 7 & Chad & 4 \\
\hline Nigeria & 7 & 7 & Congo, Rep. & 4 \\
\hline Senegal & 7 & 7 & Guinea-Bissau & 4 \\
\hline Zimbabwe & 7 & 7 & Lesotho & 4 \\
\hline Argentina & 8 & 8 & Malawi & 4 \\
\hline Australia & 8 & 8 & Jamaica & 4 \\
\hline Austri & 8 & 8 & Trinidad and Tobago & 4 \\
\hline Belgium & 8 & 8 & Uruguay & 4 \\
\hline Bolivia & 8 & 8 & Thailand & 4 \\
\hline Canada & 8 & 8 & Yemen, Rep. & 4 \\
\hline Costa Rica & 7 & 7 & China & 4.33 \\
\hline Ghana & 7 & 7 & South Africa & 5 \\
\hline Kenya & 7 & 7 & Ecuador & 5 \\
\hline Malta & 7 & 7 & Nepal & 5 \\
\hline Mozambique & 7 & 7 & Pakistan & 5 \\
\hline Cyprus & 8 & 8 & Botswana & 5 \\
\hline Denmark & 8 & 8 & Burundi & 5 \\
\hline Egypt & 8 & 8 & Egypt, Arab Rep. & 5 \\
\hline El Salvador & 8 & 8 & Guinea & 5 \\
\hline Finland & 8 & 8 & Cote d'Ivoire & 5 \\
\hline France & 8 & 8 & Mauritius & 5 \\
\hline Germany & 8 & 8 & Mozambique & 5 \\
\hline Greece & 8 & 8 & Uganda & 5 \\
\hline Guyana & 8 & 8 & Zambia & 5 \\
\hline
\end{tabular}




\begin{tabular}{|c|c|c|c|c|}
\hline COUNTRY & $\begin{array}{l}\text { FINANCIAL } \\
\text { LIBERALIZA- } \\
\text { TION INDEX }\end{array}$ & $\begin{array}{c}\text { FINANCIAL } \\
\text { LIBERALIZA- } \\
\text { TION INDEX } \\
\text { (adjusted) }\end{array}$ & $\begin{array}{c}\text { COUNTRY } \\
\text { NAME }\end{array}$ & $\begin{array}{c}\text { TELECOM } \\
\text { LIBERALIZATION } \\
\text { INDEX }\end{array}$ \\
\hline Hong Kong, China & 8 & 8 & Haiti & 5 \\
\hline Iceland & 8 & 8 & Nicaragua & 5 \\
\hline Ireland & 8 & 8 & Panama & 5 \\
\hline Israel & 8 & 8 & Argentina & 5 \\
\hline Italy & 8 & 8 & Bolivia & 5 \\
\hline Jamaica & 8 & 8 & Brazil & 5 \\
\hline Lesotho & 8 & 8 & Guyana & 5 \\
\hline Luxembourg & 8 & 8 & Paraguay & 5 \\
\hline Netherlands & 8 & 8 & Singapore & 5 \\
\hline New Zealand & 8 & 8 & Greece & 5 \\
\hline Norway & 8 & 8 & Hungary & 5 \\
\hline Panama & 8 & 8 & Iceland & 5 \\
\hline Poland & 8 & 8 & Ireland & 5 \\
\hline Portugal & 8 & 8 & Malta & 5 \\
\hline South Africa & 8 & 8 & Portugal & 5 \\
\hline Singapore & 8 & 8 & Israel & 5.33 \\
\hline Spain & 8 & 8 & Guatemala & 5.33 \\
\hline Sweden & 8 & 8 & Poland & 5.33 \\
\hline Switzerland & 8 & 8 & Venezuela & 6.33 \\
\hline Turkey & 8 & 8 & India & 6.33 \\
\hline United Kingdom & 8 & 8 & Indonesia & 6.67 \\
\hline \multirow[t]{17}{*}{ United States } & 8 & 8 & Luxembourg & 7 \\
\hline & & & Netherlands & 7 \\
\hline & & & Honduras & 7.67 \\
\hline & & & Peru & 7.67 \\
\hline & & & Sri Lanka & 7.67 \\
\hline & & & Country Name & $\begin{array}{c}\text { (Telecom lib. } \\
\text { index) }\end{array}$ \\
\hline & & & Chile & 8 \\
\hline & & & Japan & 8 \\
\hline & & & Korea, Rep. & 8 \\
\hline & & & New Zealand & 8 \\
\hline & & & Ghana & 9 \\
\hline & & & Madagascar & 9 \\
\hline & & & Tanzania & 9 \\
\hline & & & Canada & 9 \\
\hline & & & $\begin{array}{l}\text { Dominican } \\
\text { Republic }\end{array}$ & 9 \\
\hline & & & El Salvador & 9 \\
\hline & & & Mexico & 9 \\
\hline
\end{tabular}




\begin{tabular}{|c|c|c|c|}
\hline COUNTRY & $\begin{array}{cc}\text { FINAN- } & \text { FINANCIAL } \\
\text { CIAL LIB- } & \text { LIBERALIZA- } \\
\text { ERALIZAT } & \text { TION INDEX } \\
\text { ION } & \text { (adjusted) } \\
\text { INDEX } & \text { (ad }\end{array}$ & $\begin{array}{c}\text { COUNTRY } \\
\text { NAME }\end{array}$ & $\begin{array}{l}\text { TELECOM LIBER- } \\
\text { ALIZATION } \\
\text { INDEX }\end{array}$ \\
\hline & & United States & 9 \\
\hline & & Colombia & 9 \\
\hline & & Hong Kong & 9 \\
\hline & & Malaysia & 9 \\
\hline & & Philippines & 9 \\
\hline & & Austria & 9 \\
\hline & & Belgium & 9 \\
\hline & & Denmark & 9 \\
\hline & & Finland & 9 \\
\hline & & France & 9 \\
\hline & & Germany & 9 \\
\hline & & Italy & 9 \\
\hline & & Norway & 9 \\
\hline & & Spain & 9 \\
\hline & & Sweden & 9 \\
\hline & & Switzerland & 9 \\
\hline & & United Kingdom & 9 \\
\hline & & Australia & 9 \\
\hline
\end{tabular}




\section{Annex 5: Regression results}

Table 3. Regression results with telecom and financial Services indices as individual regressors Dependent variable: Growth of per-capita GNP (1990-'99)

\begin{tabular}{|c|c|c|c|c|}
\hline \multirow[t]{2}{*}{ Independent variables } & \multicolumn{3}{|c|}{ Whole sample } & $\begin{array}{l}\text { Only developing } \\
\text { countries }\end{array}$ \\
\hline & $(1)$ & $(2)$ & (3) & (4) \\
\hline Natural log of initial GNP (1990) & $\begin{array}{l}-.018 * * * \\
(-2.96)\end{array}$ & $\begin{array}{l}-.023 * * * \\
(-3.65)\end{array}$ & $\begin{array}{c}-.019 * * * \\
(-2.93)\end{array}$ & $\begin{array}{c}-.032 * * * \\
(-3.00)\end{array}$ \\
\hline Primary education enrollment (1990) & $\begin{array}{l}.039 * \\
(1.71)\end{array}$ & $\begin{array}{c}.031 \\
(1.38)\end{array}$ & $\begin{array}{l}.019 \\
(.78)\end{array}$ & $\begin{array}{c}.058 \\
(1.53)\end{array}$ \\
\hline $\begin{array}{c}\text { Lag of investment to GDP ratio } \\
\text { (1980-'89 average) }\end{array}$ & $\begin{array}{l}.172 * * * \\
(4.50)\end{array}$ & $\begin{array}{c}.195 * * * \\
(3.98)\end{array}$ & $\begin{array}{l}.219 * * * \\
(3.86)\end{array}$ & $\begin{array}{l}.220 * * * \\
(2.86)\end{array}$ \\
\hline $\begin{array}{c}\text { Government consumption to GDP } \\
\text { ratio (1990-'99 average) }\end{array}$ & $\begin{array}{l}-.193 * * * \\
(-3.20)\end{array}$ & $\begin{array}{l}-.157 * * * \\
(-2.98)\end{array}$ & $\begin{array}{l}-.159 * * * \\
(-2.77)\end{array}$ & \\
\hline $\begin{array}{c}\text { Average annual inflation rate } \\
\text { (1990-'99) }\end{array}$ & $\begin{array}{l}-.0004 \\
(-.33)\end{array}$ & $\begin{array}{l}-.001 \\
(-.86)\end{array}$ & $\begin{array}{l}-.001 \\
(-.71)\end{array}$ & \\
\hline $\begin{array}{c}\text { Dummy variable for tropical } \\
\text { countries }\end{array}$ & $\begin{array}{c}-.025 * * * \\
(-4.29)\end{array}$ & $\begin{array}{c}-.028 * * * \\
(-4.43)\end{array}$ & $\begin{array}{c}-.026 * * * \\
(-3.80)\end{array}$ & $\begin{array}{c}-.034 * * * \\
(-3.30)\end{array}$ \\
\hline Dummy for Sub-Saharan Africa & & $\begin{array}{l}-.012 \\
(-1.40)\end{array}$ & $\begin{array}{l}-.007 \\
(-.84)\end{array}$ & $\begin{array}{l}-.022 \\
(-1.39)\end{array}$ \\
\hline Dummy for Latin American countries & & $\begin{array}{c}.009 \\
(1.34)\end{array}$ & $\begin{array}{l}.013 * \\
(1.82)\end{array}$ & $\begin{array}{c}.008 \\
(1.00)\end{array}$ \\
\hline Quality of institutions & $\begin{array}{l}.0001 \\
(.07)\end{array}$ & $\begin{array}{l}.002 \\
(.96)\end{array}$ & $\begin{array}{l}.002 \\
(.75)\end{array}$ & $\begin{array}{c}.004 \\
(1.09)\end{array}$ \\
\hline Dummy variable for political stability & & $\begin{array}{l}.001 \\
(.14)\end{array}$ & $\begin{array}{l}.351 \\
(.002)\end{array}$ & \\
\hline $\begin{array}{l}\text { Telecom services trade } \\
\text { liberalization index }\end{array}$ & $\begin{array}{c}.0018 * * \\
(2.10)\end{array}$ & $\begin{array}{l}.0015 * \\
(1.71)\end{array}$ & $\begin{array}{l}.0020 * * \\
(2.12)\end{array}$ & $\begin{array}{l}.0032 * \\
(1.96)\end{array}$ \\
\hline $\begin{array}{l}\text { Financial services trade } \\
\text { liberalization index }\end{array}$ & $\begin{array}{l}.0024 * * \\
(2.23)\end{array}$ & $\begin{array}{c}.0025 * * \\
(2.30)\end{array}$ & $\begin{array}{l}.0031 * * \\
(2.62)\end{array}$ & $\begin{array}{l}.0036 * \\
(1.89)\end{array}$ \\
\hline $\begin{array}{l}\text { I.M.F. goods trade restrictiveness } \\
\text { index }\end{array}$ & $\begin{array}{l}-.003 * * \\
(-3.46)\end{array}$ & $\begin{array}{c}-.003 * * * \\
(-3.26)\end{array}$ & & $\begin{array}{l}-.003 * * \\
(-2.27)\end{array}$ \\
\hline Constant & $\begin{array}{c}.139 * * * \\
(4.53)\end{array}$ & $\begin{array}{c}.168 * * * \\
(4.65)\end{array}$ & $\begin{array}{l}.121 * * * \\
(3.62)\end{array}$ & $\begin{array}{l}.174 * * * \\
(3.70)\end{array}$ \\
\hline$R$-squared & .69 & .73 & .68 & .65 \\
\hline Number of observations & 60 & 59 & 59 & 37 \\
\hline
\end{tabular}

Note: ******indicate statistical significance at the 10 per cent, 5 per cent, and 1 per cent levels respectively. The bracketed figures indicate $t$-statistics constructed with Huber-White heteroscedasticity consistent standard errors. 
Table 4. Regressions the composite Services liberalization index as a regressor Dependent variable: Growth of per-capita GNP (1990-'99)

\begin{tabular}{|c|c|c|c|c|}
\hline \multirow[t]{2}{*}{ Independent variables } & \multicolumn{3}{|c|}{ Whole sample } & $\begin{array}{l}\text { ly developing } \\
\text { countries }\end{array}$ \\
\hline & $(1)$ & $(2)$ & (3) & (4) \\
\hline Natural log of initial GNP (1990) & $\begin{array}{c}-.018 * * * \\
(-3.04)\end{array}$ & $\begin{array}{c}-.023 * * * \\
(-3.67)\end{array}$ & $\begin{array}{l}-.014 * * \\
(-2.33)\end{array}$ & $\begin{array}{c}-.017 * * \\
(-2.58)\end{array}$ \\
\hline Primary education enrollment (1990) & $\begin{array}{l}.039 * \\
(1.73)\end{array}$ & $\begin{array}{c}.031 \\
(1.40)\end{array}$ & $\begin{array}{l}.025 \\
(1.02)\end{array}$ & $\begin{array}{l}.023 \\
(.98)\end{array}$ \\
\hline $\begin{array}{c}\text { Lag of investment to GDP ratio } \\
\text { (1980-'89 average) }\end{array}$ & $\begin{array}{l}.174 * * * \\
(4.34)\end{array}$ & $\begin{array}{l}.205 * * * \\
(3.95)\end{array}$ & $\begin{array}{l}.182 * * * \\
(3.43)\end{array}$ & $\begin{array}{l}.230 * * * \\
(3.24)\end{array}$ \\
\hline $\begin{array}{c}\text { Government consumption to GDP ratio } \\
\text { (1990-'99 average) }\end{array}$ & $\begin{array}{l}-.185 * * * \\
(-3.27)\end{array}$ & $\begin{array}{l}-.148 * * * \\
(-2.90)\end{array}$ & $\begin{array}{c}-.190 * * * \\
(-3.15)\end{array}$ & $\begin{array}{c}-.248 * * * \\
(-3.85)\end{array}$ \\
\hline $\begin{array}{c}\text { Average annual inflation rate } \\
\text { (1990-'99) }\end{array}$ & $\begin{array}{l}-.001 \\
(-.48)\end{array}$ & $\begin{array}{c}-.001 \\
(-1.09)\end{array}$ & $\begin{array}{c}-.0002 \\
(-.16)\end{array}$ & $\begin{array}{c}-.0001 \\
(-.07)\end{array}$ \\
\hline Dummy variable for tropical countries & $\begin{array}{c}-.026 * * * \\
(-4.43)\end{array}$ & $\begin{array}{c}-.029 * * * \\
(-4.36)\end{array}$ & $\begin{array}{c}-.023 * * * \\
(-3.61)\end{array}$ & $\begin{array}{c}-.030 * * * \\
(-4.20)\end{array}$ \\
\hline Dummy for Sub-Saharan Africa & & $\begin{array}{c}-.009 \\
(-1.04)\end{array}$ & & \\
\hline Dummy for Latin American countries & & $\begin{array}{c}.010 \\
(1.40)\end{array}$ & & \\
\hline Quality of institutions & $\begin{array}{c}-.00002 \\
(-.02)\end{array}$ & $\begin{array}{l}.002 \\
(.83)\end{array}$ & $\begin{array}{l}-.001 \\
(-.57)\end{array}$ & $\begin{array}{l}-.002 \\
(-.80)\end{array}$ \\
\hline Dummy variable for political stability & & $\begin{array}{l}.001 \\
(.16)\end{array}$ & $\begin{array}{l}-.001 \\
(-.19)\end{array}$ & $\begin{array}{l}-.001 \\
(-.15)\end{array}$ \\
\hline $\begin{array}{l}\text { Composite services trade } \\
\text { liberalization index }\end{array}$ & $\begin{array}{c}-.0041 * * * \\
(-2.75)\end{array}$ & $\begin{array}{c}-.0040 * * \\
(-2.53)\end{array}$ & $\begin{array}{c}-.0056 * * * \\
(-3.23)\end{array}$ & $\begin{array}{c}-.0039 * * \\
(-2.07)\end{array}$ \\
\hline $\begin{array}{l}\text { I.M.F. goods trade } \\
\text { restrictiveness index }\end{array}$ & $\begin{array}{c}-.0034 * * * \\
(-3.54)\end{array}$ & $\begin{array}{c}-.0032 * * * \\
(-3.24)\end{array}$ & & $\begin{array}{c}-.004 * * * \\
(-2.86)\end{array}$ \\
\hline Constant & $\begin{array}{c}.181 * * * \\
(4.93)\end{array}$ & $\begin{array}{l}.204 * * * \\
(4.93)\end{array}$ & $\begin{array}{l}.158 * * * \\
(3.76)\end{array}$ & $\begin{array}{l}.195^{* * * *} \\
(4.32)\end{array}$ \\
\hline$R$-squared & .68 & .73 & .64 & .78 \\
\hline Number of observations & 60 & 59 & 59 & 37 \\
\hline
\end{tabular}

Note: $*, * *, * * *$ indicate statistical significance at the 10 per cent, 5 per cent, and 1 per cent levels respectively. The bracketed figures indicate $t$-statistics constructed with Huber-White heteroscedasticity consistent standard errors. 
Table 5. Regressions with the adjusted financial Services liberalization index as a regressor Dependent variable: Growth of per-capita GNP (1990-'99)

\begin{tabular}{|c|c|c|c|}
\hline \multirow{2}{*}{ Independent variables } & \multicolumn{3}{|c|}{ Whole sample } \\
\hline & (1) & $(2)$ & (3) \\
\hline Natural log of initial GNP (1990) & $\begin{array}{c}-.017 * * * \\
(-2.70)\end{array}$ & $\begin{array}{c}-.018 * * * \\
(-2.75)\end{array}$ & $\begin{array}{c}-.018 * * * \\
(-2.78)\end{array}$ \\
\hline Primary education enrollment (1990) & $\begin{array}{c}.035 \\
(1.49)\end{array}$ & $\begin{array}{c}.035 \\
(1.43)\end{array}$ & $\begin{array}{c}.037 \\
(1.57)\end{array}$ \\
\hline Lag of investment to GDP ratio (1980-'89 average) & $\begin{array}{l}.174 * * * \\
(4.21)\end{array}$ & $\begin{array}{l}.179 * * * \\
(4.21)\end{array}$ & $\begin{array}{l}.175 * * * \\
(4.18)\end{array}$ \\
\hline $\begin{array}{c}\text { Government consumption to GDP ratio } \\
\text { (1990-'99 average) }\end{array}$ & $\begin{array}{c}-.176^{* * * *} \\
(-3.11)\end{array}$ & $\begin{array}{c}-.175 * * * \\
(-3.07)\end{array}$ & $\begin{array}{c}-.169 * * * \\
(-3.09)\end{array}$ \\
\hline Average annual inflation rate (1990-'99) & $\begin{array}{l}-.001 \\
(-.83)\end{array}$ & $\begin{array}{l}-.001 \\
(-.81)\end{array}$ & $\begin{array}{l}-.001 \\
(-.96)\end{array}$ \\
\hline Dummy variable for tropical countries & $\begin{array}{c}-.027 * * * \\
(-4.57)\end{array}$ & $\begin{array}{c}-.027 * * * \\
(-4.62)\end{array}$ & $\begin{array}{c}-.027 * * * \\
(-4.56)\end{array}$ \\
\hline Quality of institutions & $\begin{array}{c}-.00002 \\
(-.015)\end{array}$ & $\begin{array}{l}-.0002 \\
(-.019)\end{array}$ & $\begin{array}{c}-.0001 \\
(-.11)\end{array}$ \\
\hline Dummy variable for political stability & & $\begin{array}{l}-.001 \\
(-.21)\end{array}$ & \\
\hline Telecom services trade liberalization index & $\begin{array}{l}.0015 * \\
(1.81)\end{array}$ & $\begin{array}{l}.0018 * * \\
(2.04)\end{array}$ & \\
\hline $\begin{array}{c}\text { Adjusted financial services trade liberalization } \\
\text { index }\end{array}$ & $\begin{array}{c}.0027 * * \\
(2.17)\end{array}$ & $\begin{array}{c}.0026 * * \\
(2.14)\end{array}$ & \\
\hline $\begin{array}{c}\text { Composite services trade liberalization index } \\
\text { (adjusted) }\end{array}$ & & & $\begin{array}{c}.004 * * * \\
(2.72)\end{array}$ \\
\hline I.M.F. goods trade restrictiveness index & $\begin{array}{c}-.003 * * * \\
(-3.30)\end{array}$ & $\begin{array}{c}-.003 \\
(-3.31)\end{array}$ & $\begin{array}{c}-.0035 * * * \\
(-3.46)\end{array}$ \\
\hline Constant & $\begin{array}{c}.136^{* * *} \\
(4.40)\end{array}$ & $\begin{array}{c}.141 * * * \\
(4.17)\end{array}$ & $\begin{array}{c}.140 * * * \\
(4.55)\end{array}$ \\
\hline$R$-squared & .68 & .69 & .68 \\
\hline Number of observations & 60 & 59 & 60 \\
\hline
\end{tabular}

Note: $*, * *, * * *$ indicate statistical significance at the 10 per cent, 5 per cent, and 1 per cent levels respectively. The bracketed figures indicate $t$-statistics constructed with Huber-White heteroscedasticity consistent standard errors. 
Table 6. Regressions with individual dummy variables for full liberalization of telecom and financial Services

Dependent variable: Growth of per-capita GNP (1990-'99)

\begin{tabular}{|c|c|c|c|c|}
\hline \multirow{2}{*}{ Independent variables } & \multicolumn{2}{|c|}{ Whole sample } & \multicolumn{2}{|c|}{ Only developing countries } \\
\hline & $(1)$ & $(2)$ & (3) & $(4)$ \\
\hline Natural log of initial GNP (1990) & $\begin{array}{c}-.022 * * * \\
(-3.33)\end{array}$ & $\begin{array}{c}-.026 * * * \\
(-4.00)\end{array}$ & $\begin{array}{c}-.027 * * * \\
(-3.31)\end{array}$ & $\begin{array}{c}-.027 * * * \\
(-3.22)\end{array}$ \\
\hline Primary education enrollment (1990) & $\begin{array}{l}.049 * * \\
(2.25)\end{array}$ & $\begin{array}{l}.042 * * \\
(2.05)\end{array}$ & $\begin{array}{l}.074 * * \\
(2.34)\end{array}$ & $\begin{array}{l}.075 * * \\
(2.34)\end{array}$ \\
\hline $\begin{array}{c}\text { Lag of investment to GDP ratio } \\
\text { (1980-'89 average) }\end{array}$ & $\begin{array}{l}.162 * * * \\
(4.16)\end{array}$ & $\begin{array}{l}.201 * * * \\
(3.92)\end{array}$ & $\begin{array}{l}.227 * * * \\
(4.07)\end{array}$ & $\begin{array}{l}.210 * * * \\
(3.20)\end{array}$ \\
\hline $\begin{array}{c}\text { Government consumption to GDP } \\
\text { ratio (1990-'99 average) }\end{array}$ & $\begin{array}{l}-.221 * * * \\
(-3.90)\end{array}$ & $\begin{array}{l}-.183 * * * \\
(-3.38)\end{array}$ & & \\
\hline $\begin{array}{c}\text { Average annual inflation rate } \\
\text { (1990-'99) }\end{array}$ & $\begin{array}{l}-.001 \\
(-.55)\end{array}$ & $\begin{array}{l}-.001 \\
(-1.24)\end{array}$ & $\begin{array}{l}-.003 \\
(-1.31)\end{array}$ & $\begin{array}{l}-.003 \\
(-1.29)\end{array}$ \\
\hline $\begin{array}{c}\text { Dummy variable for tropical } \\
\text { countries }\end{array}$ & $\begin{array}{c}-.030 * * * \\
(-4.34)\end{array}$ & $\begin{array}{c}-.033 * * * \\
(-4.74)\end{array}$ & $\begin{array}{c}-.037 * * * \\
(-4.20)\end{array}$ & $\begin{array}{c}-.036^{* * * *} \\
(-3.99)\end{array}$ \\
\hline Dummy for Sub-Saharan Africa & & $\begin{array}{l}-.006 \\
(-.60)\end{array}$ & & \\
\hline Dummy for Latin American countries & & $\begin{array}{c}.011 \\
(1.53)\end{array}$ & & \\
\hline Quality of institutions & $\begin{array}{l}.0002 \\
(.13)\end{array}$ & $\begin{array}{l}.002 \\
(.95)\end{array}$ & $\begin{array}{l}.002 \\
(.61)\end{array}$ & $\begin{array}{l}.002 \\
(.59)\end{array}$ \\
\hline Dummy variable for political stability & $\begin{array}{l}-.004 \\
(-.67)\end{array}$ & $\begin{array}{l}-.001 \\
(-.09)\end{array}$ & & $\begin{array}{l}-.006 \\
(-.74)\end{array}$ \\
\hline $\begin{array}{l}\text { Dummy variable for full } \\
\text { liberalization of telecoms }\end{array}$ & $\begin{array}{l}.013^{*} \\
(1.87)\end{array}$ & $\begin{array}{l}.010^{*} \\
(1.84)\end{array}$ & $\begin{array}{l}.019 * * \\
(2.10)\end{array}$ & $\begin{array}{l}.019 * * \\
(2.14)\end{array}$ \\
\hline $\begin{array}{l}\text { Dummy variable for full } \\
\text { liberalization of financial services }\end{array}$ & $\begin{array}{l}.013 * * * \\
(2.67)\end{array}$ & $\begin{array}{l}.012 * * \\
(2.35)\end{array}$ & $\begin{array}{l}.021 * * \\
(2.13)\end{array}$ & $\begin{array}{l}.023 * * \\
(2.05)\end{array}$ \\
\hline $\begin{array}{c}\text { I.M.F. goods trade restrictiveness } \\
\text { index }\end{array}$ & $\begin{array}{c}-.004 * * * \\
(-3.62)\end{array}$ & $\begin{array}{c}-.004 * * * \\
(-3.28)\end{array}$ & $\begin{array}{c}-.005 * * * \\
(-3.37)\end{array}$ & $\begin{array}{c}-.005 * * * \\
(-3.40)\end{array}$ \\
\hline Constant & $\begin{array}{l}.196 * * * \\
(4.69)\end{array}$ & $\begin{array}{l}.206^{* * * *} \\
(4.75)\end{array}$ & $\begin{array}{l}.167 * * * \\
(3.37)\end{array}$ & $\begin{array}{l}.174 * * * \\
(3.26)\end{array}$ \\
\hline$R$-squared & .70 & .73 & .62 & .63 \\
\hline Number of observations & 59 & 59 & 37 & 37 \\
\hline
\end{tabular}

Note: $*, * *, * * *$ indicate statistical significance at the 10 per cent, 5 per cent, and 1 per cent levels respectively. The bracketed figures indicate $t$-statistics constructed with Huber-White heteroscedasticity consistent standard errors. 
Table 7. (Dummy variable for full liberalization of telecom and financial services) Dependent variable: Growth of per-capita GNP (1990-'99)

\begin{tabular}{|c|c|c|c|c|}
\hline \multirow[t]{2}{*}{ Independent variables } & \multicolumn{2}{|c|}{ Whole sample } & \multicolumn{2}{|c|}{$\begin{array}{l}\text { Only developing } \\
\text { countries }\end{array}$} \\
\hline & (1) & $(2)$ & (3) & (4) \\
\hline Natural log of initial GNP (1990) & $\begin{array}{c}-.019 * * * \\
(-2.69)\end{array}$ & $\begin{array}{c}-.024 * * * \\
(-3.49)\end{array}$ & $\begin{array}{l}-.018 * * \\
(-2.28)\end{array}$ & $\begin{array}{l}-.022 * * \\
(-2.49)\end{array}$ \\
\hline Primary education enrollment (1990) & $\begin{array}{l}.052 * * \\
(2.10)\end{array}$ & $\begin{array}{l}.042 * \\
(1.92)\end{array}$ & $\begin{array}{l}.038 \\
(1.53)\end{array}$ & $\begin{array}{c}.035 \\
(1.44)\end{array}$ \\
\hline $\begin{array}{c}\text { Lag of investment to GDP ratio } \\
\text { (1980-'89 average) }\end{array}$ & $\begin{array}{c}.166^{* * *} \\
(3.75)\end{array}$ & $\begin{array}{l}.205^{* * * *} \\
(3.36)\end{array}$ & $\begin{array}{l}.227 * * * \\
(3.00)\end{array}$ & $\begin{array}{l}.306^{* * * *} \\
(3.11)\end{array}$ \\
\hline $\begin{array}{c}\text { Government consumption to GDP ratio } \\
\text { (1990-'99 average) }\end{array}$ & $\begin{array}{c}-.209 * * * \\
(-3.46)\end{array}$ & $\begin{array}{c}-.165 * * * \\
(-3.04)\end{array}$ & $\begin{array}{c}-.261 * * * \\
(-3.92)\end{array}$ & $\begin{array}{c}-.235 * * * \\
(-3.37)\end{array}$ \\
\hline $\begin{array}{l}\text { Average annual inflation rate } \\
\text { (1990-'99) }\end{array}$ & $\begin{array}{r}-.001 \\
(.73)\end{array}$ & $\begin{array}{l}-.002 \\
(-1.56)\end{array}$ & $\begin{array}{l}-.0004 \\
(-.33)\end{array}$ & $\begin{array}{l}-.001 \\
(-.87)\end{array}$ \\
\hline $\begin{array}{c}\text { Dummy variable for tropical } \\
\text { countries }\end{array}$ & $\begin{array}{c}-.026 * * * \\
(-4.04)\end{array}$ & $\begin{array}{c}-.030 * * * \\
(-4.33)\end{array}$ & $\begin{array}{l}-.031 * * * \\
(-3.93)\end{array}$ & $\begin{array}{c}-.037 * * * \\
(-4.25)\end{array}$ \\
\hline Dummy for Sub-Saharan Africa & & $\begin{array}{l}-.009 \\
(-1.05)\end{array}$ & & $\begin{array}{l}.005 \\
(.41)\end{array}$ \\
\hline Dummy for Latin American countries & & $\begin{array}{c}.012 \\
(1.44)\end{array}$ & & $\begin{array}{c}.015 \\
(1.40)\end{array}$ \\
\hline Quality of institutions & $\begin{array}{l}-.0004 \\
(-.26)\end{array}$ & $\begin{array}{l}.002 \\
(.84)\end{array}$ & $\begin{array}{l}-.002 \\
(-.80)\end{array}$ & $\begin{array}{r}-.001 \\
(.31)\end{array}$ \\
\hline Dummy variable for political stability & $\begin{array}{l}-.003 \\
(-.45)\end{array}$ & $\begin{array}{l}.001 \\
(.08)\end{array}$ & $\begin{array}{l}-.003 \\
(-.39)\end{array}$ & $\begin{array}{l}.001 \\
(.13)\end{array}$ \\
\hline $\begin{array}{l}\text { Dummy variable for full } \\
\text { liberalization of both sectors }\end{array}$ & $\begin{array}{l}.015^{* *} \\
(2.18)\end{array}$ & $\begin{array}{l}.015^{* *} \\
(2.21)\end{array}$ & $\begin{array}{l}.025^{* *} \\
(2.14)\end{array}$ & $\begin{array}{l}.028 * * \\
(2.64)\end{array}$ \\
\hline $\begin{array}{l}\text { I.M.F. goods trade restrictiveness } \\
\text { index }\end{array}$ & $\begin{array}{c}-.004 * * * \\
(-3.70)\end{array}$ & $\begin{array}{c}-.004 * * * \\
(-3.32)\end{array}$ & $\begin{array}{c}-.005 * * * \\
(-3.07)\end{array}$ & $\begin{array}{c}-.004 * * \\
(-2.49)\end{array}$ \\
\hline Constant & $\begin{array}{c}.170 * * * \\
(4.17)\end{array}$ & $\begin{array}{c}.190 * * * \\
(4.33)\end{array}$ & $\begin{array}{c}.182^{* * *} \\
(3.83)\end{array}$ & $\begin{array}{c}.185^{* * * *} \\
(3.32)\end{array}$ \\
\hline$R$-squared & .67 & .71 & .76 & .78 \\
\hline Number of observations & 59 & 59 & 37 & 37 \\
\hline
\end{tabular}

Note: *,**,*** indicate statistical significance at the 10 per cent, 5 per cent, and 1 per cent levels respectively. The bracketed figures indicate $t$-statistics constructed with Huber-White heteroscedasticity consistent standard errors. 